\title{
THE EFFECTS OF HYPOXAEMIA ON CEREBRAL BLOOD FLOW AND CEREBROSPINAL FLUID PRESSURE IN DOGS ANAESTHETIZED WITH ALTHESIN, PENTOBARBITONE AND METHOXYFLURANE
}

\author{
R.S. COHEN, M.B., B.S., F.F.A.R.A.C.S., F.R.C.P.(c), \\ H.I.A. NisBeT, M.B., CH.B., F.F.A.R.C.S., F.R.C.P.(c), R.E. CREIGHTON, M.D., F.R.C.P.(C), \\ D.J. STEWARD, M.B., B.S., F.R.C.P.(c), AND \\ P. McDonald, M.B., B.S., M.R.C.P.(E), F.F.R., F.R.C.P.(c) \\ with the technical help of G. Volgyesi AND L. Joyal
}

\section{INTRODUCTION}

Pentobarbitone, low concentrations of methoxyflurane and Althesin (Glaxo CT 1341) ${ }^{*}$ do not increase cerebral blood flow or cerebrospinal fluid pressure in the dog. ${ }^{1,2}$ Therefore, these agents may be suitable for use during neuroradiological examinations in patients with raised intracranial pressure.

Different types and depths of anaesthesia modify the cardiovascular response to arterial hypoxaemia. As part of a continuing study of these responses we investigated changes in cerebral blood flow $(\mathrm{CBF})$, oxygen transport $\left(\mathrm{CTaO}_{2}\right)$ and cerebrospinal fluid (CSF) pressure occurring in dogs subjected to severe arterial hypoxaemia during anaesthesia with these agents.

\section{Methons}

Three groups of beagle dogs were studied. In the first group (seven dogs) anaesthesia was induced with Althesin, $4.8-5.0 \mathrm{mg} / \mathrm{kg}$ and maintained with 24 $\mathrm{mg}$ increments of this agent. In the second group (five dogs) anaesthesia was induced with intravenous pentobarbitone $30 \mathrm{mg} / \mathrm{kg}$ and maintained with $50 \mathrm{mg}$ increments. In the third group (four dogs) anaesthesia was induced with intravenous pentobarbitone, $30 \mathrm{mg} / \mathrm{kg}$ and maintained with 0.3 per cent methoxyflurane. The dogs were all intubated with a cuffed tracheal tube and were ventilated with air by a Harvard pump to maintain a normal arterial carbon dioxide tension $\left(\mathrm{PaCO}_{2}\right)$. Temperature was measured with a rectal probe and the dog was placed on a heated water blanket to keep the temperature normal.

From the Department of Anaesthesia, The Research Institute, The Hospital for Sick Children, Toronto, Canada; and the Departments of Anaesthesia, The University of Toronto, Toronto, Canada.

Address for reprints: Dr. R.S. Cohen, Deparment of Anaesthesia, The Hospital for Sick Children, 555 University Avenue, Toronto, M5G 1X8, Ontario, Canada.

Supported in part by a grant from the Canadian Red Cross Youth (Ontario).

Paper read by Dr. R.S. Cohen at the Annual Meeting of the Canadian Anaesthetists' Society, Halifax, Nova Scotia, June, 1972.

${ }^{\circ}$ Glaxo CT 1341@: Glaxo-Allenburys, Toronto, Ontario.

Canad. Anaesth. Soc. J., vol. 20, no. 6, November 1973 
Using a modified Seldinger technique we cannulated the vertebral artery through a femoral artery. Catheters were also inserted into the right atrium through a femoral vein and into the aorta through the contralateral femoral artery.

We measured $\mathrm{pH}$, oxygen and carbon dioxide tensions of arterial blood $\left(\mathrm{PaO}_{2}\right.$ and $\mathrm{PaCO}_{2}$ ) using a radiometer electrode system and corrected values for temperature. Arterial blood pressure was monitored continuously with a Bell and Howell transducer and the Brush amplifier recorder system. Cardiac output (Q) was measured by dye dilution using a Waters cuvette and densitometer. Cerebrospinal fluid pressure was measured continuously through a 19-gauge needle inserted into the cisterna magna and connected to a Bell and Howell transducer and a Brush amplifier and recorder.

A collimated scintillation probe, positioned over the dog's skull, was connected through a pulse height analyzer to an analogue rate meter, the output of which was displayed on an X-Y recorder. We measured cerebral blood flow by analyzing the appearance and rate of clearance of a bolus of $\mathrm{Xe}^{133}$ into the vertebral artery. One millicurie of $\mathrm{Xe}^{133}$ dissolved in $1 \mathrm{ml}$ of saline was injected and the catheter was flushed immediately with $2 \mathrm{ml}$ saline.

When a steady state had been established during anaesthesia with one of the agents under investigation, control values were obtained while the dog breathed air. Hypoxaemia was then induced for a period of 15 to 35 minutes by substituting an appropriate mixture of oxygen and nitrogen for the air, in the inspired mixture, After 10 to 15 minutes of hypoxaemia, when the arterial oxygen tension remained steady at less than $30 \mathrm{~mm} \mathrm{Hg}$, the measurements of cerebral blood flow were made. Cerebrospinal fluid pressure, arterial blood gases, mean arterial blood pressure, heart rate and cardiac output were measured during the period of hypoxaemia. Following the hypoxaemic period the dogs were ventilated with air for 30 to 40 minutes and the measurements were repeated.

Preliminary studies showed that, during recovery from pentobarbitone anaesthesia, cerebral blood flow and cerebrospinal fluid pressure fell to values close to initial values. These measurements were therefore omitted in the last three test animals.

To show the effect of hypoxaemia on cerebral blood flow in dogs lightly anaesthetized with pentobarbitone 0.3 per cent methoxyflurane, 1 per cent halothane and Althesin, we combined values obtained in the present study with those of Gray $^{5}$ ( 24 experiments).

\section{Results}

During anaesthesia with the three agents examined this degree of hypoxaemia caused significant increases in both cerebral blood flow and cerebrospinal fluid pressure (Tables I and II).

During recovery from hypoxaemia both cerebral blood flow and cerebrospinal fluid pressure fell to values close to initial values.

The effect of hypoxaemia on cardiac output and mean arterial blood pressure in dogs anaesthetized with Althesin and methoxyflurane are shown in Table III. The expected increases in cardiac output and mean arterial blood pressure were 
TABLE I

The Effect Of Hypoxaemia on Cerebral Blood Flow

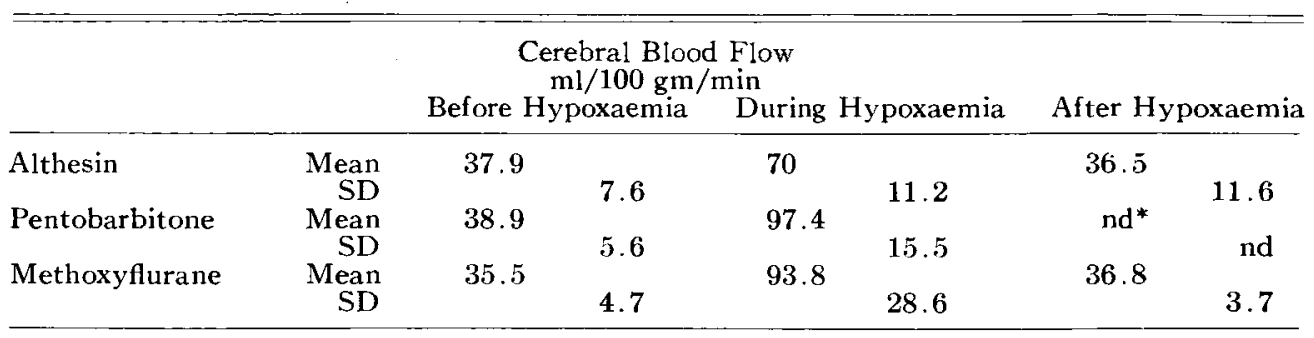

*Not done.

TABLE II

The Effect of Hypoxaemia on Cerebral Spinal fluid Pressure

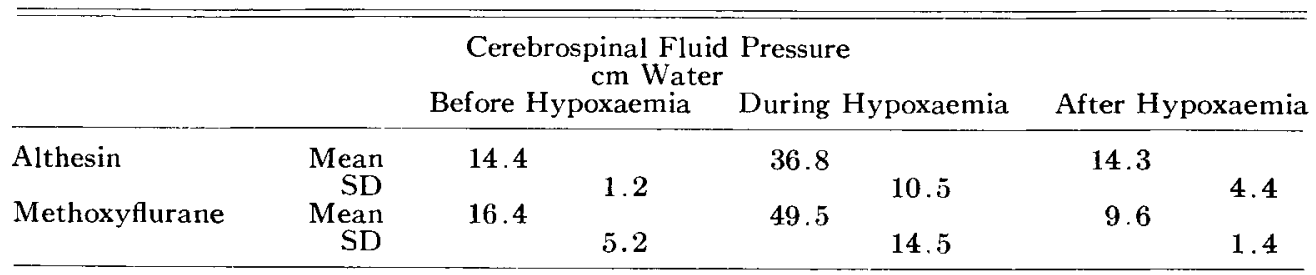

TABLE III

The Effect of Hypoxaemia on Cardiac Output and Mean Arterial Blood Pressure

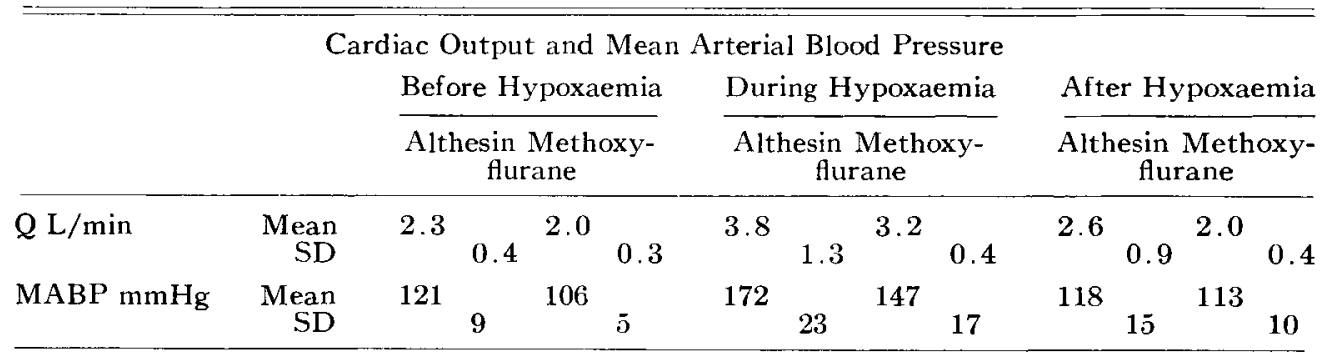

TABLE IV

The Effect of Hypoxaemia on Arterial Blood Gases, pH

\begin{tabular}{|c|c|c|c|c|c|c|c|}
\hline \multicolumn{8}{|c|}{ Blood Gases, $\mathrm{pH}$} \\
\hline \multirow[b]{3}{*}{$\mathrm{PaO}_{2}$} & \multirow[b]{3}{*}{$\begin{array}{c}\text { Mean } \\
\text { SD }\end{array}$} & \multirow{2}{*}{\multicolumn{2}{|c|}{$\frac{\text { Before Hypoxaemia }}{\begin{array}{c}\text { Althesin Methoxy- } \\
\text { flurane }\end{array}}$}} & \multirow{2}{*}{\multicolumn{2}{|c|}{$\begin{array}{c}\text { During Hypoxaemia } \\
\begin{array}{c}\text { Althesin Methoxy- } \\
\text { flurane }\end{array}\end{array}$}} & \multirow{2}{*}{\multicolumn{2}{|c|}{ 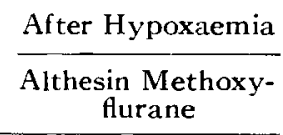 }} \\
\hline & & & & & & & \\
\hline & & $91.7_{7.2}^{1}$ & 101 & $28.2_{2.9}$ & 23.6 & $\begin{array}{r}88.6 \\
6.7\end{array}$ & ${ }_{7.0}^{92.5}$ \\
\hline $\mathrm{PaCO}_{2} \mathrm{mmHg}$ & $\begin{array}{c}\text { Mean } \\
\text { SD }\end{array}$ & ${ }_{1.8}^{35.3}$ & 34 & $\begin{array}{ll}34 & \\
& 3.8\end{array}$ & $\begin{array}{r}38.5 \\
3.0\end{array}$ & ${ }^{35} 2.5$ & $\begin{array}{ll}37 & \\
& 0.8\end{array}$ \\
\hline $\mathrm{pH}$ units & $\begin{array}{c}\text { Mean } \\
\text { SD }\end{array}$ & $\begin{array}{l}7.37 \\
0.03\end{array}$ & $\begin{array}{r}7.43 \\
0.03\end{array}$ & $\begin{array}{l}7.38 \\
0.03\end{array}$ & $\begin{array}{l}7.36 \\
0.02\end{array}$ & $\begin{array}{l}7.38 \\
0.02\end{array}$ & $\begin{array}{l}7.39 \\
0.01\end{array}$ \\
\hline $\begin{array}{l}\text { Base Excess } \\
\mathrm{mEq} / \mathrm{L}\end{array}$ & $\underset{\text { SD }}{\text { Mean }}$ & $\begin{array}{r}-3.5 \\
1.0\end{array}$ & $\begin{array}{r}-1.2 \\
0.5\end{array}$ & $\frac{-3.5}{2.4}$ & $\begin{array}{r}-4.2 \\
0.5\end{array}$ & $\begin{array}{r}-4.3 \\
0.8\end{array}$ & $\begin{array}{r}-3.5 \\
0.6\end{array}$ \\
\hline
\end{tabular}


TABLE $\mathrm{V}$

The Effect of Hypoxaemia on Cerebral Available Oxygen

\begin{tabular}{|c|c|c|c|c|c|c|c|}
\hline \multirow{4}{*}{$\begin{array}{l}\text { Althesin } \\
\text { Methoxyflurane }\end{array}$} & \multirow{4}{*}{$\begin{array}{l}\text { Mean } \\
\text { SD } \\
\text { Mean } \\
\text { SD }\end{array}$} & \multirow{2}{*}{\multicolumn{2}{|c|}{$\begin{array}{r}\mathrm{ml} / 100 \mathrm{gm} \\
\text { Before Hypoxaemia }\end{array}$}} & \multirow{2}{*}{\multicolumn{2}{|c|}{ During Hypoxaemia }} & \multirow{2}{*}{\multicolumn{2}{|c|}{ After Hypoxaemia }} \\
\hline & & & & & & & \\
\hline & & 7.7 & \multirow{2}{*}{1.6} & 8.0 & 2.4 & 8.5 & 2.5 \\
\hline & & 7.0 & & 6.4 & & 7.2 & 2.0 \\
\hline
\end{tabular}

observed during hypoxaemia. The effect of hypoxaemia on arterial blood gases and $\mathrm{pH}$ are shown in Table IV. The arterial oxygen tension was reduced to less than $30 \mathrm{~mm} \mathrm{Hg}$ as planned and the $\mathrm{PaCO}_{2}$ maintained at normal levels during hypoxaemia. Table $\mathrm{V}$ shows that cerebral available oxygen was well maintained during hypoxaemia. The combined results of hypoxaemia on changes in cerebral blood flow during light anaesthesia are shown in Figure 1.

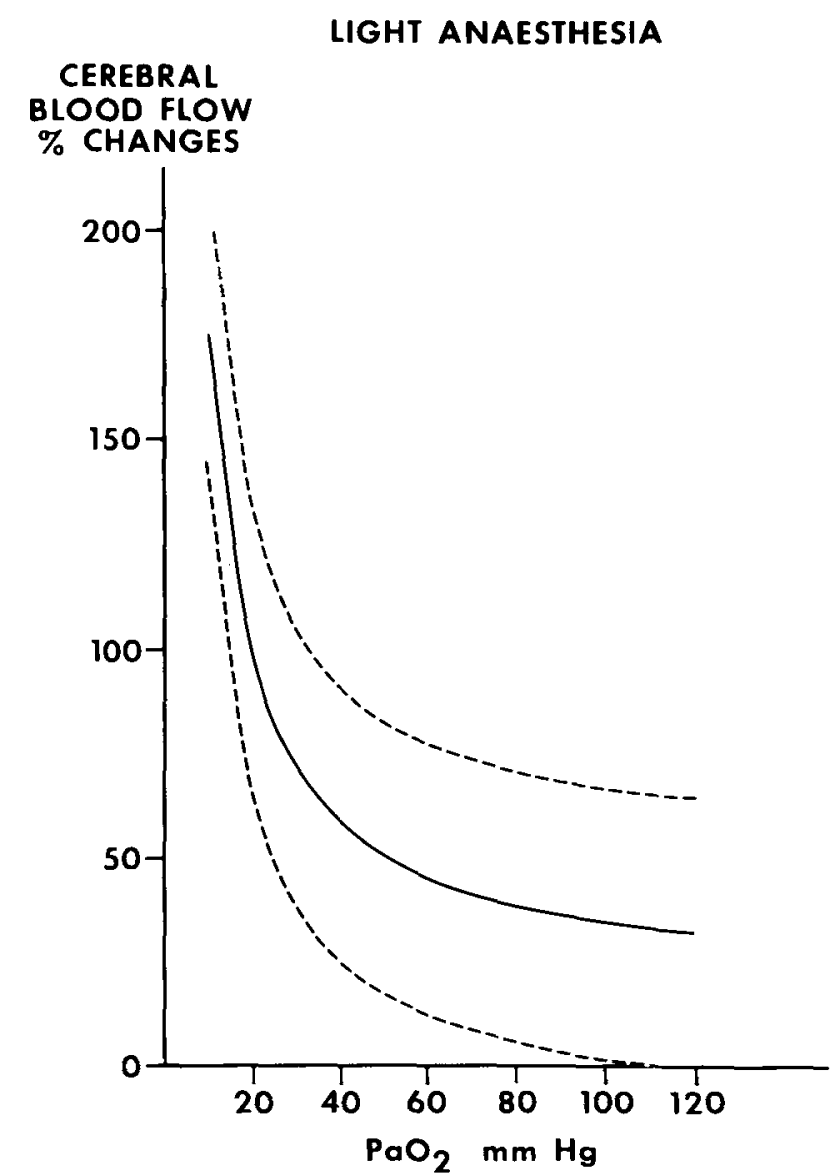

Figure 1. Regression line with 95 per cent limits showing relationship between cerebral blood flow and $\mathrm{PaO}_{2}$ in 24 dogs lightly anaesthetized with Althesin, 0.3 per cent methoxyflurane, 1 per cent halothane and pentobarbitone (combined results of Cohen and Gray). 


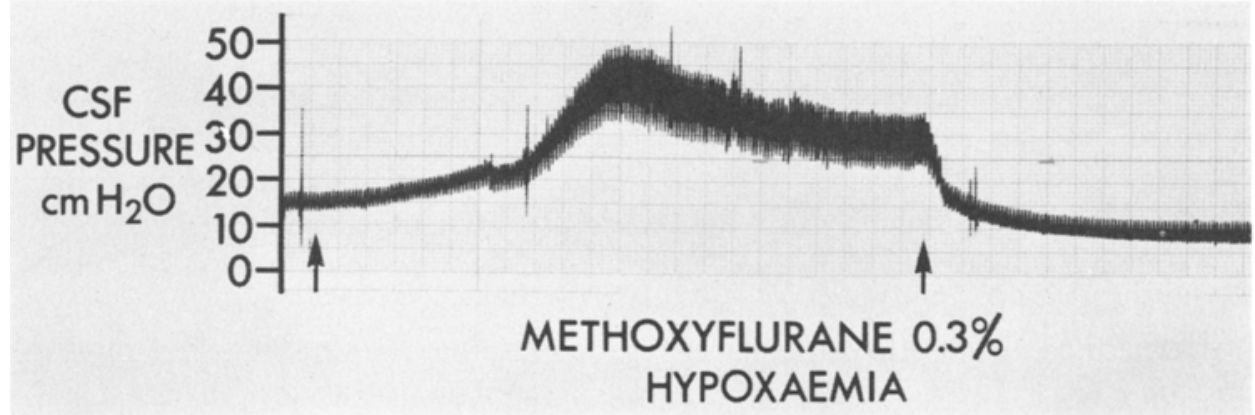

Frcure 2. Showing the increase of cerebrospinal fluid pressure following the onset of hypoxia (first arrow) and the return to normal levels following restoration of normoxia (second arrow).

Figure 2 is a typical tracing showing the increases in cerebrospinal fluid pressure during hypoxaemia.

All the dogs survived the period of hypoxaemia and regained consciousness. Upon recovery they showed no signs of cerebral damage.

\section{Discussion}

The mean cerebral oxygen consumption in conscious man is about $3.5 \mathrm{ml} / 100$ $\mathrm{gm} / \mathrm{min}^{3}$ In our studies the amount of oxygen carried to the brain during hypoxaemia was approximately twice this amount. Even assuming no change in haemoglobin concentration, cerebral oxygen transport must have been high during hypoxaemia. McDowall ${ }^{4}$ reported a reduction in cerebral oxygen consumption of between 14 and 33 per cent during general anaesthesia. Complete recovery of all dogs suggests that during anaesthesia with Althesin and 0.3 per cent methoxyflurane, sufficient oxygen is available during hypoxaemia for cerebral metabolic needs. Recovery was poor in dogs subjected to deeper anaesthesia with 1.5 per cent halothane, 0.6 per cent methoxyflurane and 1.5 per cent trichloroethylene. ${ }^{5}$

The increase in cerebral blood flow caused by hypoxaemia in dogs anaesthetized with pentobarbitone or methoxyflurane was greater than in those given Althesin. This may be in part because $\mathrm{PaO}_{2}(28 \mathrm{~mm} \mathrm{Hg})$ was higher in dogs anaesthetized with Althesin than in those anaesthetized with pentobarbitone ( 22 $\mathrm{mm} \mathrm{Hg}$ ) or methoxyflurane $(23.6 \mathrm{~mm} \mathrm{Hg})$. The steepest rise in cerebral blood flow appears to occur during light anaesthesia when $\mathrm{PaO}_{2}$ is reduced to below $24 \mathrm{~mm} \mathrm{Hg}$ (Figure 1).

During recovery from hypoxaemia we detected no luxury perfusion and in this respect our model differs from patients who have suffered cerebral circulatory arrest. $^{6}$

Cerebrospinal fluid pressure rose rapidly to a maximum within ten minutes of the onset of hypoxaemia and remained elevated throughout the period of hypoxaemia but it plateaued and gradually fell from the maximum level in the latter part of the hypoxaemic period. The increase in cerebrospinal fluid pressure was rapidly reversed by restoring normal oxygenation suggesting that the intracranial pressure returned to normal after the hypoxaemic incident (Figure 2). 


\section{SUMMARY}

Althesin and 0.3 per cent methoxyflurane, unlike other volatile anaesthetic agents, ketamine and higher concentrations of methoxyflurane do not increase cerebral blood flow or cerebrospinal fluid pressure in dogs. Recently Althesin has been reported to cause a fall in cerebrospinal fluid pressure. ${ }^{7}$

Accordingly, Althesin may prove to be useful in neuroradiology and neurosurgery especially as it is associated with rapid return of consciousness.

Anaesthesia with Althesin, and 0.3 per cent methoxyflurane does not interfere with the dog's response to severe arterial hypoxaemia to an extent that impairs cerebral oxygen transport. The increases in cerebral blood flow and cerebrospinal fluid pressure during hypoxaemia are striking but brief.

\section{RÉSUMÉ}

L'althesine et 0.3 pour cent de méthoxyflurane, à l'encontre des autres anesthésiques volatils, de la kétamine et de concentration plus élevée de méthoxyflurane, n’augmentent pas le flot sanguin cérébral de la pression du liquide céphalorachidien chez les chiens. On a rapporté récemment que l'althésine cause une chute de pression du liquide céphalo rachidien.

De ce fait, l'althésine peut se révéler utile en neuroradiologie et en neurochirurgie, d'autant plus qu'elle est associée à un retour rapide de la conscience.

L'anesthésie avec althésine et 0.3 pour cent de méthoxyflurane n’interfère pas avec la réponse des chiens à l'hypoxémie artérielle sévère au point de diminuer le transport cérébral d'oxygène. L’augmentation du flot sanguin cérébral et de la pression du liquide céphalo rachidien pendant l'hypoxémie sont marqués, mais de courte durée.

\section{Acknowledgments}

We wish to thank Dr. W. Zingg and his staff for the use of facilities in the Animal Research Laboratories, The Hospital for Sick Children, Toronto.

We would also like to express our thanks to Glaxo (Canada) for their supply of Althesin.

\section{REFERENCES}

1. Gray, I.G., Mitra, S.K., Nisbet, H.I.A., Aspin, N., \& Creighton, R.E. The effect of methoxyflurane on cerebral blood flow in the dog. Can. Anaesth. Soc. J. 18: 408 (1971).

2. Cohen, R.S., Stewamd, D.J., Nisbet, H.I.A., Creighton, R.E., \& McDonald, P. The effects of CT 1341 on cerebral blood flow and intracranial pressure. Abstract for the Fifth World Congress of Anaesthesiologists. September, 1972.

3. Wollman, H., Alexander, S.C., Cohen, P.J., Chase, P.E., Melman, E., \& Behar, M.G. Cerebral circulation of man during halothane anethesia. Effects of hypocarbia and of d-tubocurarine. Anesthesiology 25: 180 ( 1964).

4. McDowall, D.G. The effects of clinical concentrations of halothane on the blood flow and oxygen uptake of the cerebral cortex. Br. J. Anaesth. 39: 186 (1967).

5. Gray, I.G., Mrtra, S.K., Nisbet, H.I.A., Aspin, N., \& Creighton, R.E. Cerebral blood flow in hypoxemic anesthetized dogs. Anesth. Analg. 50: 594 (1971).

6. Hahper, A.M. \& MCDowall, D.G. Luxury perfusion. III. International Symposium Lund-Copenhagen, 1968, edited by D.H. Ingvar, N.A. Lassen, B.K. Siesjö, et al. Scand. J. Lab. and Clin. Invest. 22: Suppl. 102: X:B. 1968.

7. Turner, J.M., Coroneos, N.J., Gibson, R.M., Powell, D., Ness, M.A., \& McDowall, D.G. The effect of althesin on intracranial pressure in man. Br. J. Anaesth. 45: 168 (1973). 